\title{
Abolition or mitigation of the death penalty A perspective on the laws of Israel
}

\author{
F.N. Lion-Cachet \\ Dept. Old \& New Testament \\ Potchefstroom University for CHE \\ POTCHEFSTROOM
}

\begin{abstract}
The issue concerning the topic of the death penalty for capital offences is still widely discussed. Those supporting the retention of the death penalty mostly quote the Old Testament as their source of authority. The question, however, is whether confirnation has not been found too easily in the Old Testament, without fully taking into account the conditions of the period. Or should the death penalty not be applied for transgressions other than manslaughter as well? In this paper special attention will be given to the demand for the death penalty for manslaughter and other crimes. The question whether the implementation of the death penaly in the history of old Israel implies the retention or mitigation thereof, will also have to be answered.
\end{abstract}

\section{Introductory}

In most ancient laws of Israel the death penalty is compulsory for various crimes. The question, however, remains whether the death penalty for manslaughter should not be reconsidered when the conditions of the period in which the laws of old Israel were fonmulated, are taken into consideration. Can the death penalty for religious, ceremonial and moral transgressions be so easily disregarded? Pleas for abolition because of a possible rehabilitation of the criminal, as well as calls for a greater compliance with the laws of the Old Testament are heard today (Geisler, 1990:193-199; NGK, 1986:98-100). The question thus remains whether the death penalty should be abolished, extended or maintained for murder only?

In this article the following point of departure is used: The Old Testament is accepted as an authoritative book of faith - a book based on the fact that the Lord, the God of Israel is one. The relationship between God and man is clarified in the Old Testament. As authoritative Word the Old Testament also contains fundamental truths which hold good for all people. From this point of view the Old Testament data will be examined, evaluated and placed in a historicalrevelationary perspective. 


\section{The death penalty in various books of law}

The old books of law are taken as point of departure for the research of clearly defined decrees. Although many Old (and New) Testament laws are given in the course of the narration of historical events (cf. Gen. 2:16-17, 24; 9:1-7; Lev. 24:10-16; Num. 15:32-36, 22:1-11, 36:1-9) (Brongers, 1960:175), the Mosaic laws given at Sinai can be regarded as the beginning of the formulation of the judicial principle. In the course of history law books have gradually been compiled and handed on to the next generation. During this process the usual practical applications and editing took place until we have the present completed form (Boecher, 1980:53-56).

\section{The Book of the Covenant}

The Book of the Covenant is one of the oldest law collections. Usually the history of development is taken into account when considering these laws (cf. Brongers, 1960:181 e.g.; Fensham, 1977:23; Childs, 1974:452). These laws form, to a great extent, the nucleus on which the other law books are built (Fohrer, 1968: 181-183; Noth, 1965: 147; Klopper, 1988:153). In the following discussion, the 21 capital crimes (Geisler, 1990:200) are divided into sections for the sake of convenience.

\section{- Religious crimes}

In Scripture, man's relationship to God is central (Deut. 6:4). However being insignificant, man was created to honour the eternal God. No human being can destroy God, but man's words and deeds can violate the honour of God. Therefore the cursing of God is forbidden (Ex. 22:27 (NIV 28)), because the concept of cursing (P) implies making something small or insignificant (cf. Keller, 1976:641-647). Cursing is an attempt to destroy with words. Whosoever blasphemes the Name of God, must pay the highest price. The culprit must "surely die" (a מוֹת יוּמָת-decree) (Lev. 24:16). A typical מוֹת ירּקָ-decree requires urgent execution (cf. Boecher, 1980:193-5). Idol worshippers (Ex. 22:19 (NIV 20)) and witches (Ex. 22:17 (NIV 18)) were also subject to the death penalty (Fensham, 1970:170; Noth, 1962:186).

In ancient Eastern legal codes, such as the Codex Hammurabi, a cultic judicial system is not directly mentioned - the laws were purely social. The administration of justice was the responsibility, not of the priests, but of appointed officials (Brongers, 1960:38). 


\section{- Ceremonial trespasses}

No laws requiring the death penalty are stated in the Book of the Covenant In Exodus 19:12, however, approaching the mountain of legislation (law giving) is

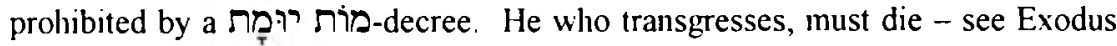
30:20-21 and 31:14-15 (Noth, 1962:241)

\section{- Manslaughter crimes}

In Exodus 21:12-17 a series of casuistic or semi-casuistic laws, concluded by a מוֹת ירוּמת -formula is found. These laws apply to a murderer, one who curses his parents, a kidnapper or one who trades in human beings (slave-trader). This attests to the high value placed on the sanctity of human life (cf. Fensham, 1977:40)

In Exodus 21:13 and 14, two casuistic decrees have been inserted (Fohrer, 1968: 69-70) - laws concerning the intention of the deed. According to Exodus 21:13 and 14 one who unintentionally kills another, must flee to a place appointed by God. The culprit could also flee to the altar to obtain a fair trial, an ancient Easten practice (Gray, 1964:94; Noth, 1962.180). From earliest antiquity no practice of inexorable legal revenge existed in Israel.

In Exodus 21:22-25 we find the Jus talıons: this was the criterion for the judges to apply if a pregnant woman had received a blow causing an injury (cf. Fensham, 1970:155-156, Kaiser, 1983:174). It is possible that the original formula contained only a life-for-a-life principle, and that the extensions were later additions (Daube, 1969:115). The fus taluonis was also an ancient Eastern custom (cf. the Codex Hammurabi. The Jus talionis is also implicit in a more modern custom in Northern Africa - see Alt, 1934:303-304).

The supposition that the intention of casuistic laws was that the punishment should fit the crime should be rejected. In the ancient East ordinary citizens (awelum) sometimes received dispropontionate punishments or were executed for minor misdeeds. The jus talionis was thus not a justification for revenge, but an attempt to limit irresponsible vengeance (cf. Fensham, 1977:34; Pritchard, 1971: 161-162). Although this repulsive fonnula was later superseded, it did not disappear suddenly, but did so as the authoritarian structure itself became more clearly defined. In Israel standard legal procedures became customary in the monarchical period (Childs, 1974:470; Thompson, 1974:216). From the beginning the equivalent punishments were placed next to the jus talionis in the old legal codes.

Murder and manslaughter and the ensuing revenge were part of the old Eastern way of life. In the old codes noticeably few casuistic laws existed - laws which merited the death penalty. In the Codex Hammurabi the death penalty was required for perjury, kidnapping, perverted sexulal practices and blows leading to fatal miscarriages $(1-2,14,130,210$ - cf. Pritchard, 1971). No example of mur- 
der, as defined in Exodus 21:12 is mentioned. It thus seems as if the concept of the value of human life was completely lacking in the ancient East.

The basis for the death penalty for manslaughter must be sought in Genesis 9:6. This text is usually included in the Priestly Codex, which is considered as a late priestly collection of old traditions and laws. The editor(s), however, dated the formation, however ancient it might be, after the Flood and before the history of Abraham. Thereby they made the revelationary truth, however it might have been handed down in tradition, applicable to mankind. The principle was therefore probably familiar to most of the compilers of the law books (from the Book of the Covenant and later manuscripts) (cf. Gispen, 1974:296).

The origin and the value of the formulation of the principle have been the cause of much deliberation and argument, but it need not necessarily imply a mechanical inspiration theory (cf. Henry, 1986:230-234; Reid, 1986:231-246; Klopper, 1988: 160; Van Selms, 1967:123).

The principle of the death penalty has been handed down as an old fonmula with a neat poetic structure:

Whoever sheds the blood of man,

by man his blood shall be shed.

In this formula the emphasis is on blood, which has a close connection with human life. Blood plays an important role in the provisions for capital punishment (cf. Lev. 20:11, 12, 13, 16). Capital punishment begins with the blood of Abel, which calls for vengeance (Gen. 4:10). More important, however, is the motivation for punishment for in the image of God God has made man. In Genesis 9:6 we find a revelation of the true faith which is found nowhere else. The statement in Genesis 9:6 relates to Genesis $1: 26$ and 27 where the relationship of man to God and God to his creation is described (cf. Vriezen, 1966;186-190). Man is never seen as an absolute being separate from God or in opposition to Him; he finds his existence and dignity in his commitment to God. Basically the high esteem of man implies his being the image or representative of God (Heyns, 1989:159). Nobody can kill God and nobody may kill his representative. $\mathrm{He}$ who lifts his hand against man, lifts it against God. This pre-Israelitic motivation holds good for all mankind.

This point of departure is in sharp contrast to the view of the ancient East - a view according to which human beings were created by the gods, but out of clay, to be their slaves (cf. Henry, 1986:239). Human life was regarded as insignificant and fleeting. 


\section{- Moral misdeeds}

Sexual transgressions are not extensively treated in the Book of the Covenant. A few other rules appear in Exodus 21:17 and 22:19.

\section{The tradition of the priests in Leviticus and Numbers}

Leviticus and Numbers, as part of the so-called Priestly Codex, are usually seen as a priestly collection of earlier traditions and texts containing a wide variety of genres and origin. Various developmental stages can be identified in the codex, of which certain subcollections can be recognized, e.g. the "Holiness Code" (cf. Fohrer, 1968:181; Rendtorff, 1985:145, 147). The laws originated in the SinaiMoses-period and later (cf. Childs, 1979:184; Noth, 1965:179).

\section{- Religious misdeeds}

The rules of the Book of the Covenant were applied, refined and extended (cf. Lev. 20:27; Ex. 22:18; Lev. 24:10-16; Ex. 22:28) (Noth, 1965:179-180). This is true for ceremonial transgressions too (Lev. 10:1-2, 9; 16:2; Num. 3:4, 15:32-36; also cf. Ex. 31:14-15 and 35:2). In Numbers several rules concerning the tabernacle and cultic services are mentioned $(1: 51 ; 3: 10,38 ; 4: 15,19-20 ; 17: 13 ; 18: 3$, 7). These rules imply that culprits had to pay with their lives (18:32). The laws are stated in a casuistic way - the implication being that God will execute the sentence (see Nadab and Abihu in Lev. 10:1-2 and the death of Uzzah, 2 Sam. 6:7). The usurpers in the priesthood had to die as the priesthood was assigned exclusively to Aaron and his descendants.

\section{- Manslaughter crimes}

Capital punishment for a murderer is repeatedly mentioned in Leviticus 24:17 and 21. The condition for the execution of the death penalty and the role of the avenger of blood are not clearly defined in the Old Testament. The places of asylum, namely the free cities, are however, clearly stated in Numbers. Free cities were possibly known outside Israel (Von Rad, 1966:128; Thompson, 1974:216). The free cities gave one who had unintentionally killed another or even a murderer the opportunity of having a fair trail (Childs, 1974:470).

The accused had to be tried by a legal tribunal. This meeting (עָדجד) was probably the gathering of spiritual leaders of the city (cf. Lev. 1:16;10:2). They had to try the case on the grounds of sufficient evidence. The grounds for judging whether it was a case of murder punishable by death, are mentioned (cf. Maarsingh, 1987:119). Circumstantial evidence, such as the weapons used and what could have caused death was regarded as of vital importance. The motive, however, was more important. It was reasoned that the deed must either have been committed intentionally or out of hate or enmity. Manslaughter, committed un- 
intentionally or on the spur of the moment could be regarded as having mitigating circumstances.

If a person was found guilty, the avenger of blood, usually the nearest relative (Num. 35:19, הרָּ, the redeemer of blood - see Ringgren, 1975:352; Daube, 1969:124; Stamm, 1971:387; Craigie, 1976:266) had to carry out the sentence. No ransom or atonement money (פ⿹ $(\neg)$ could be accepted (Num. 35:31) (cf. Childs, 1974:473; Maass, 1971:843).

\section{- Moral misdeeds}

A special contribution in the "Holiness Code" (Childs, 1979:182-183) for the people of Israel, is the emphasis on sexual transgressors. In most instances sexual transgressors "had surely to be put to death" (Lev. 20:10-21). God would also punish them with childlessness (Lev. 20:20).

Leviticus 20:1-27 stresses the holiness of the LORD and demands the holiness of the people. Holiness (and purity) in marriage and in human relationships are highly esteemed. Although a typical מוֹת יד:מָת-formula is not used (a participle and short description), a transgression is nonetheless punishable by a מרת רקיָמָת.

\section{Deuteronomy}

Many researchers accept that the book Deuteronomy is a collection of traditional material, especially laws, written by various authors or editors of one school of thought - authors/editors who worked on it for a long time. The final form is ascribed to the reformation in the days of Josiah. Various stages in finalizing these laws are recognized and the existence of a Proto Deuteronomy is accepted (Rendtorff, 1985:155). In the book Deuteronomy the collection is presented as speeches of Moses delivered before the Israelites entered the promised land. When thus considered, the legal principles held sway from the beginning of Israel's sojourn in Palestine.

Many laws show a great similarity to those of the Book of the Covenant, but some are abridged, while most are worked out in greater detail.

\section{- Religious decrees}

In Deuteronomy various transgressions concerning the relationship with God are noted, of which the most important is the worship of other gods as a merited cause for the death penalty (cf. 13:1-18). Special attention was paid to the manner in which legal matters were judged. This was true for all crimes. There had to be a thorough investigation (17:4), justice had to be done after sufficient evidence had been gathered (cf. 19:5; 17:6); a false witness could be executed (19:16, 18). In Deuteronomy 17:8 and the following verses the trial in the city gates is 
mentioned: if the case could not be resolved there, it had to be brought to a place chosen by God (cf. Llewellyn, 1975:10,11).

\section{- Manslaughter crimes/misdeeds}

In Deuteronomy 19:1-13 a number of casuistic laws for fair trails in free cities is emphasized. The laws contained guidelines like the following: the elders were involved in the course of justice, the attitude of the accused had to be taken into account, the evidence had to be tested, a false witness was not to be excused. In Deuteronomy 19 the jus talionis is partly repeated: A life for a life (19:21). Although the מורת ירוּמת-formula is not used here, the death penalty is mentioned, as also the stipulation that no mercy should be shown to the murderer (Craigie, 1976:268).

\section{- Moral transgressions}

According to Deuteronomy $21: 18-21$ a son who is disobedient, out of control, a drunkard and a wastrel, is to be stoned after a proper trial. The body of someone who deserved the death penalty and was executed, could be hung on a gibbet as he was accursed of God (21:22-23). This 'crucifixion' was not an execution of the death penalty, but a way to deter the people from breaking certain stipulations of the covenant (Craigie, 1976:285). Women guilty of illegal pre-marital sex (22:13-21) and other sexual transgressions (22:22-26) were to be stoned.

\section{Summary}

* The old Testament teaching emphasizes the fact that God is one, and stresses the relationship between Him and man (Deut. 6:4-5). Nobody can destroy God, but words and deeds could bring about God's contempt Therefore the laws of Israel (Ex. 22:27(28)) included the following words: You shall not blaspheme (curse) (God. The blaspheming of God was punishable with a specific kind of death (Lev. 24:16). The death penalty was compulsory for false prophets and the transgressors of certain ceremonial instifutions where the holy presence of God was visibly revealed.

* The death penalty was also compulsory (the מוֹת ירמּת -stipulation) for premeditated murder or kidnapping (Ex. 21:12-14; Lev. 24:17).

In Exodus 21:22-25 (cf. Deut. 19:21; Lev. 24:20) the jus talionis is quoted. Ethical motives cause scholars to attempt a mitigation of the law by a figurative interpretation. This would mean that the punishment had to fit the crime. In the ancient East the jus talionis was an attempt to counteract excessive revenge. This must not be seen as a right to vengeance, but as a way to limit uncontrolled revenge. From the beginning the equivalent punishments were also placed next to the jus talionis 
Murder and manslaughter and the ensuing revenge were part of the ancient Eastern way of life. Regarding these aspects it seems as if the concept of the value of human life lacked entirely. Man was seen as a slave of gods made out of clay. On the other hand, the value of human life is clearly revealed in the history of the revelation in the Old Testament and it can be regarded as a foundation for later legislation.

The death penalty is founded on the pre-lsraelitic law as it is found in Genesis 9:6. The motivation for this law is that man is made in the image of God. Therein is contained a truth in God's revelation which demands the recognition of all people of all times. Man has a inviolable dignity as image and representative of God. This immunity could only be violated at the expense of the death penalty.

* With regard to moral transgressions the death penalty sometimes sounds excessive. Moral transgressions are addressed in the so-called holiness laws: sexual transgressions had to be punished by death (Lev. 20:10-21). These decrees demand the acknowledgement of the holiness of God in the life of the people of Israel (Lev. 19:2; 20:7).

* In the law codes the requirement of a fair trial is well defined. However, the instructions regarding the execution of the death penalty and the role of the avenger of blood are not clear. Clarity came in part with the stipulation of free cities (Num. 35:9-34). The free cities offered a suspect the opportunity of having a fair trial. The criteria for judgement leading to the death penalty were clearly defined and the possibilities for mitigating the death sentence were emphasized.

\section{Examples of the application of death penalty stipulations}

The historical narratives in the Pentateuch and the so-called Deuteronomistic narratives supply examples of the application of the laws.

\section{- Religious and ceremonial stipulations}

According to Genesis 3 man disobeyed God's commandment by eating of the tree of knowledge of good and evil and thus had to pay with his life (Gen. 2:17). God punished man and woman, but not with immediate death - man would die but later (Gen. 3:19). The validity of the death penalty was therefore not prejudiced, but was merely postponed.

In 2 Samuel 6 the story of Uzzah, who held to the ark and was struck down by God, is related. According to Numbers 4:15 it was the task of the sons of Kohath to carry the ark. As in Leviticus 10 the LORD Himself executed the death penalty. 


\section{- Manslaughter crimes}

In Genesis 4:1-16 the story of Cain who killed Abel is related. This act was regarded as murder (cf. Ex. 21.12), a deed committed out of jealousy and unbelief (cf. Heb. 11:4). The LORD Himself tried the case and passed judgement. Cain did not undergo the death penalty, but he, however, was cursed. Calvin (1847: 210-211) asks whether this curse was an appropriate punishment for murder and points out the awfulness of Cain's exile and the perpetual unrest in his soul. The fact, however, remains that Cain was not condemned to death.

God's actions need not be questioned or criticized, but it is meaningful trying to understand God's intention. Cain had to pay with his life, but God first gave him the opportunity to live for a while under severe trials. Was it a concession giving Cain time to reform (become converted)? Was it because there were so few people? Was it to give an example of how, under certain circumstances, mercy could be shown? Was it the abolition of the death penaity? In similar vein we can continue speculating. What, however, remains certain is the fact that the validity of the death penalty was not in question. In later laws it was clearly stipulated that a murderer had to be executed. God wanted it thus.

Moses was a witness of how an Egyptian killed a Hebrew (Exodus 2:11-14)(cf. Noth, 1962:35-36) and thereupon he killed the Egyptian. Israelite laws stipulated that, in order to punish a murderer, it was essential that eye witnesses should give evidence. Moses' revenge on the Egyptian was a kind of judicial execution. Moses thought that God would bring salvation through his deed (cf. Acts 7:24-25 and 35). Moses committed this deed on the spur of the moment - nonetheless it became known at the court of the Pharaoh and he intended to execute Moses. Moses thus had to flee for his life. In his later life as 'lawgiver', this incident was never referred to and his eventual death was not regarded as punishment for murder.

David was an adulterer and a murderer (2 Samuel 11-12) and there was probably sufficient evidence of his misdeeds (Geisler, 1990:197). The LORD's punishment for the murder and adultery was the curse that David's house would never again rest from the sword and his wives would be dishonoured. Bathsheba's child would also die. David however, was excused (cf. Hertzberg, 1964:314). It should have been a double death penalty for a sexual crime and murder. Many questions arise, but it is clear that God did not abolish the death penalty. He did not punish David with death, but an odour of death clung to David.

According to 2 Samuel 13:14 Amnon dishonoured his sister, Tamar, and had to be put to death. Without a fair trial Absalom had Amnon killed (2 Sam. 13:32). Absalom fled from the wrath of David, but was later allowed to return (14:24). This history highlights disorderly government and court intrigues, but not the abolition of the death penalty (Hertzberg, 1964:330). 
In the following instances, the death penalty was applied: Joab, David's commander-in-chief, killed Abner, the son of Ner (2 Sam 3:22-27, 39) and Amasa, the son of Jeter (2 Sam. 20:4-10). There is grave doubt whether Joab was justified in these deeds (Gray, 1964:98). David unjustly reprieved Joab, but eventually Solomon had him executed (1 Kings 2:31-34).

\section{- Moral transgressions}

Shimei cursed the king (2 Sam. 16:10). Cursing the king was considered as a crime and could result in the application of the death penalty (Ex. 22:27). In the mentioned instance the death penalty was later carried out ( 1 Kings 2:8, 9, 37, 46). Another instance of a moral transgression is the incident where Adonijah plotted to become king after David's death (1 Kings 1:5, 25). He, however, feared the wrath of Solomon and later fled to the altar, clinging to the horns of the altar (1:50). By touching the altar, he was entitled to a fair trial. He was reprieved, but later executed (1 Kings 2:24-25). Abiathar, who conspired with Adonijah against David (1:7) was exempted from the death penalty but was banished to Anatot.

\section{Summary}

\section{- Religious and ceremonial stipulations}

According to Genesis 3 man sinned by transgressing God's commandment, which he gave as a special stipulation to Adam and Eve. God, however, reprieved them by not executing an immediate physical death sentence. Leviticus 10 (Nadab and Abihu) and 2 Samuel 6 (Uzzah) relate incidents where religious transgressions are punished according to prescriptions in the Israelitic laws.

\section{- Murder}

Examples of murderers who deserved the death penalty, as laid down in principle (Gen. 9:6) and in the Israelitic laws (int. al. Ex. 21:12-14), but who were reprieved, occur in the revelationary history. Cain was reprieved, the life of Moses was spared and the death penalty for the adultery and murder by David was not executed by God or the authorities. The reprieve was neither arbitrary nor inconsistent (in contrast to Shelley's view - 1984:16), because there were reasons, although they were not always clear to us. In these stories, however, no legal or judicial stipulations concerning the abolition of the death sentence or the scrapping of the principle followed.

In 2 Samuel 13 and 14; 2 Samuel 3:22-27, 39; 1 Kings 1 and 2 the deaths of murderers are related. Many aspects reveal only badly managed government and court intrigues, but the abolition of the death penalty is not the issue at stake. 


\section{- Moral transgressions}

Regarding moral transgressions we can refer to Shimei, who cursed the king (2 Sam. 16:7), to Adonijah who plotted against Solomon and Abiathar (1 Kings 2:26), who conspired with him (1:7). These incidents do not illustrate the abolition of the death penalty; at best they only serve as examples of a temporary reprieve.

\section{Conclusion}

In conclusion it can be stated that the various laws and stipulations regarding the death penalty for religious, life-protecting, ceremonial and moral transgressions should in first instance be positioned in their narrow Israelite and in their broader human context. Following upon this, the application of these laws can be tested in the course of revelationary history.

The few examples illustrating breaches of the law, which were punishable by death, clearly emphasize that in general no deduction can be made regarding the validity of the retention or abolition of the death penalty as such. The following, however, must be taken into consideration:

* Israelitic laws bound to a specific tume and historical context, cannot easily be applied as timeless principles. In the light of the New Testament, in which the ceremonial and religious laws were abolished to a great extent (cf. Acts 15:28-29), the stipulations of the Old Testament laws should be reevaluated. This re-evaluation will also affect the punishment regarding the breach of moral laws.

* Regarding the death penalty for fatal crimes (manslaughter), there is, however, a sound foundation in the principle which is firmly rooted in the Old Testament. The relationship between God and man is emphasized in an exceptional way. Man is the image of God and therefore the value of human life is held in high esteem. Man's immunity to murder could only be violated at the cost of incurring the death penalty. To argue against the death penalty for intentional murder is difficult. The death penalty is God's inviolable institution (cf. Engelbrecht, 1992:8).

* Regarding the conviction or reprieve of criminals guilty of taking a human life, the guideline was that reprieve could only be granted on strength of a thorough and sincere investigation. According to Old Testament guidelines fair and compassionate trial is always demanded and revenge is not permitted - thus the Old Testament makes ample provision for mitigating circumstances.

One principle remains clear and uncompromising: the individual human being, no matter how insignificant, is important in the eyes of God, as he is the only crea- 
ture made in God's image. To kill him is to offend against God's own institution. With due regard for motivation and mitigating circumstances, the death penalty can therefore still be justified in modern society. The death penalty is one of the means by which man is protected from mindless violence by his own fellow-man, a law first formulated by a just and merciful God Himself.

\section{Bibliography}

ALT, A 1934. Zur Talionsformel Zeitschrift für die alttestamentliche Wissenschaft, 52: 303-305.

BOECHER, H.J 1980. Law and the Administration of Justice in the Old Testament and Ancient East London : SPCK

BRONGERS, H. A 1960. Oud-Oosters en Bijbels recht. Nijkerk : Callenbach

CALVIN, J 1847. Commentaries on the First Book of Moses Called Genesis Translator: King, J Edinburgh : Edinburgh Printing.

CHILDS, B S 1974 Exodus [OTL]. London : SCM

CHILDS, B S. 1979. Introduction to the Old Testament as Scripture London : SCM

CRAIGIE, P.C. 1976. The Book of Deuteronomy [NICOT] Grand Rapids : Eerdmans

DAUBE, D 1969. Studies in Biblical Law New York: KTAV

ENGELBRECHT, B 1992 Diskussie oor die doodstraf waar begin ons? Tydskrif wir die Geesteswetenskappe, 32:1:1-12

FENSHAM, FC. 1970. Exodus [POT] Nijkerk: Callenbach

FENSHAM, FC. 1977. Transgression and Penalty in the Book of the Covenant Code Journal of Northwest Semitic Ianguages, 5:233-41

FOHRER, G. 1968 Introduction to the Old Testament Translator: Green, D E Nashville Abingdon

GEISLER, N L 1990. Christian Ethics Options and Issues Grand Rapids Baker Bookshop

GISPEN, W.H 1974 Genesis I [COT] Kampen: Kok

GRAY, J 19641 \& Il Kings A Commentary [OTL] London: SCM

HENRY, C.F.H 1986 Does Genesis 9 Justify Capital Punishment? Yes (In Youngblood, R ed. The Genesis Debate Nashville Thomas Nelson p 230-250.)

HERTZBERG, HW 1964 I \& II Samuel [OTL] London SCM

HEYNS, J A 1989 Teologiese etiek 2/2. Pretoria NG KerkBoekhandel

KAISER, W.C. [Jr]. 1983. Toward Old Testament Ethics Grand Rapids : Zondervan

KELLER, C.A. קלל (In Jenni, E., Westermann, C Theologisches Handworterbuch zum Alten Testament II Munchen : Kaiser. p 641-647.)

KLOPPER, Frances 1988. Doodstraf in die Ou-Testamentiese perspektief. Pon Elizabeth UPE (Verhandeling - M A)

LLEWELLYN, D 1975 Restoring the Death Penalty Proceed with Caution Christianity Today, 19(17):10-17.

MAARSINGH, B. 1987. Numbers A Practical Commentary Grand Rapids Eerdmans

MAASS, F 1971 כפר (In Jenni, E., Westermann, C Theologisches Handwornerbuch zum Alten Testament I Munchen Kaiser p 842-857.)

NEDERDUITSE GEREFORMEERDE KERK [NGK] 1986 Handelinge van die sewende vergadering van die Algemene Sinode van die Nederduitse Gereformeerde Kerk Bloemfontein NG Sendingpers.

NOTH, M (1962) 1965 Leviticus [OTL] London SCM

NOTH, M 1962 Exodus [OTL] London SCM 
PRITCHARD, J B (R) 1971 The Ancient Near East - An Anthology of Texts and Pictures London : Oxford

REID, M A 1986 Does Genesis 9 Justify Capital Punishment? No (In Youngblood, R ed., The Genesis Debate Nashville : Thomas Nelson p 230-250)

RENDTORFF, R 1985. The Old Testament An Introduction Translator Bowden, J London : SCM

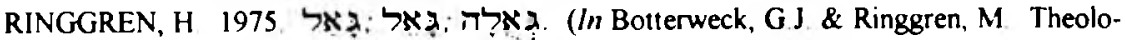
gical Dictionary of the Old Testament II Grand Rapids : Eerdmans p. 350-355.)

SHELLEY, M. 1984. The Death Penalty Two Sides of a Growing Issue Christianity Today, 28(4): 14-19.

STAMM, J.J 1971. גאר. (In Jenni, E \& Westermann, C Theologisches Handworterbuch zum Alten Testament I. München : Kaiser p. 383-394)

THOMPSON, J A 1974. Deuteronomy [TOTC] London: IVP

VAN SELMS, A 1967. Genesis I [POT] Nijkerk: Callenbach

VON RAD, G 1966. Deuteronomy [OTL] London : SCM

VRIEZEN, Th C. 1966 Hoofdlijnen der theologie van het Oude Testament Wageningen Veenman. 
